\title{
Hildegard E. Peplau, Selected Works
}

\section{Interpersonal Theory in Nursing}


Anita Werner O'Toole, R.N., C.S., Ph.D. received her master's degree in psychiatric nursing from Rutgers University, New Brunswick, New Jersey, USA and her doctoral degree in sociology from Case Western Reserve University, Cleveland, Ohio, USA. She is currently Professor and Director of the Graduate Program in Psychiatric Mental Health Nursing at Kent State University, Kent, Ohio, USA. She also maintains a part-time private psychotherapy practice with adults and families. Dr O'Toole has published extensively in both nursing and sociology. Her recent research publications are in the areas of family violence and development of a classification system for psychiatric nursing diagnosis.

Sheila Rouslin Welt, R.N., M.S. received her master's degree in psychiatric nursing from Rutgers University, New Brunswick, New Jersey, USA. As a psychotherapist working with children and adults, she is currently in private practice of psychotherapy and clinical supervision in New York and New Jersey. She has presented lectures and workshops throughout the US and abroad and has an extensive list of publications to her credit. In 1963, she co-authored Group Psychotherapy In Nursing Practice, the first book on group psychotherapy by a nurse. Her co-authored book, Issues in Psychotherapy, received the 1982 American Journal of Nursing Book of the Year award. Her 1983 co-authored book, A Collection of Classics in Psychiatric Nursing Literature, was chosen as the 1983 Book of the Year by the American Journal of Nursing. Volume II of Issues in Psychotherapy, tentatively renamed Narcissism And The Therapist-Patient Relationship, was published in 1989. 


\section{Hildegard E. Peplau, Selected Works}

\section{Interpersonal Theory in Nursing}

Edited by

Anita Werner O'Toole, R.N., C.S., Ph.D. Sheila Rouslin Welt, R.N., M.S.

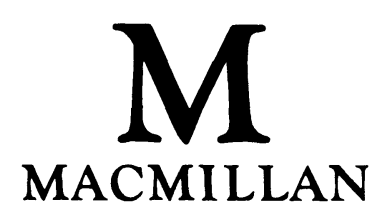


(C) Springer Publishing Company, Inc. 1989

(C) Introduction to this edition Howard Simpson 1994

All rights reserved. No reproduction, copy or transmission of this publication may be made without written permission.

No paragraph of this publication may be reproduced, copied or transmitted save with written permission or in accordance with the provisions of the Copyright, Designs and Patents Act 1988, or under the terms of any licence permitting limited copying issued by the Copyright Licensing Agency, 90 Tottenham Court Road, London W1P 9HE.

Any person who does any unauthorised act in relation to this publication may be liable to criminal prosecution and civil claims for damages.

First published in 1989 by Springer Publishing Company, Inc.

536 Broadway

New York, NY 10012

This edition first published 1994 by

THE MACMILLAN PRESS LTD

Houndmills, Basingstoke, Hampshire RG21 2XS

and London

Companies and representatives

throughout the world

A catalogue record for this book is available from the British Library.

ISBN 978-0-333-60964-4 ISBN 978-1-349-13441-0 (eBook)

DOI 10.1007/978-1-349-13441-0 


\section{Contents}

Foreword by Grayce Sills viii

Acknowledgments $x i$

Introduction xiii

Introduction to this edition by Howard Simpson xix

PART I: Interpersonal Relations Theory

Introduction

1. Interpersonal Relationships in Psychiatric Nursing 5

2. Theory: The Professional Dimension 21

3. Interpersonal Relationships: The Purpose and Characteristics of Professional Nursing 42

4. Interpersonal Constructs for Nursing Practice 56

PART II: Therapeutic Milieu

Introduction

5. The History of Milieu as a Treatment Modality 75

6. Psychiatric Nursing: The Nurse's Role in

Preventing Chronicity

7. General Application of Theory and Techniques of Psychotherapy in Nursing Situations 99

8. Pattern Interactions 108

9. Psychiatric Nursing: Role of Nurses and Psychiatric Nurses 


\section{PART III: The Teaching of Psychiatric Nursing}

Introduction

10. What Is Experiential Teaching?

11. Interpretation of Clinical Observations

12. Clinical Supervision of Staff Nurses

\section{PART IV: Psychotherapy}

Introduction

13. Interpersonal Techniques: The Crux of Psychiatric Nursing

14. Psychotherapeutic Strategies

15. Therapeutic Nurse-Patient Interaction

16. Investigative Counseling

17. Professional Closeness

18. Themes in Nursing Situations

\section{PART V: Concepts}

Introduction

19. Loneliness

20. Theoretical Constructs: Anxiety, Self, and Hallucinations

21. Thought Disorder in Schizophrenia: Corrective Influence of Nursing Behavior on Language of Patients

22. An Explanatory Theory of the Process of Focal Attention

23. Process and Concept of Learning

Editors' Summary

Index 


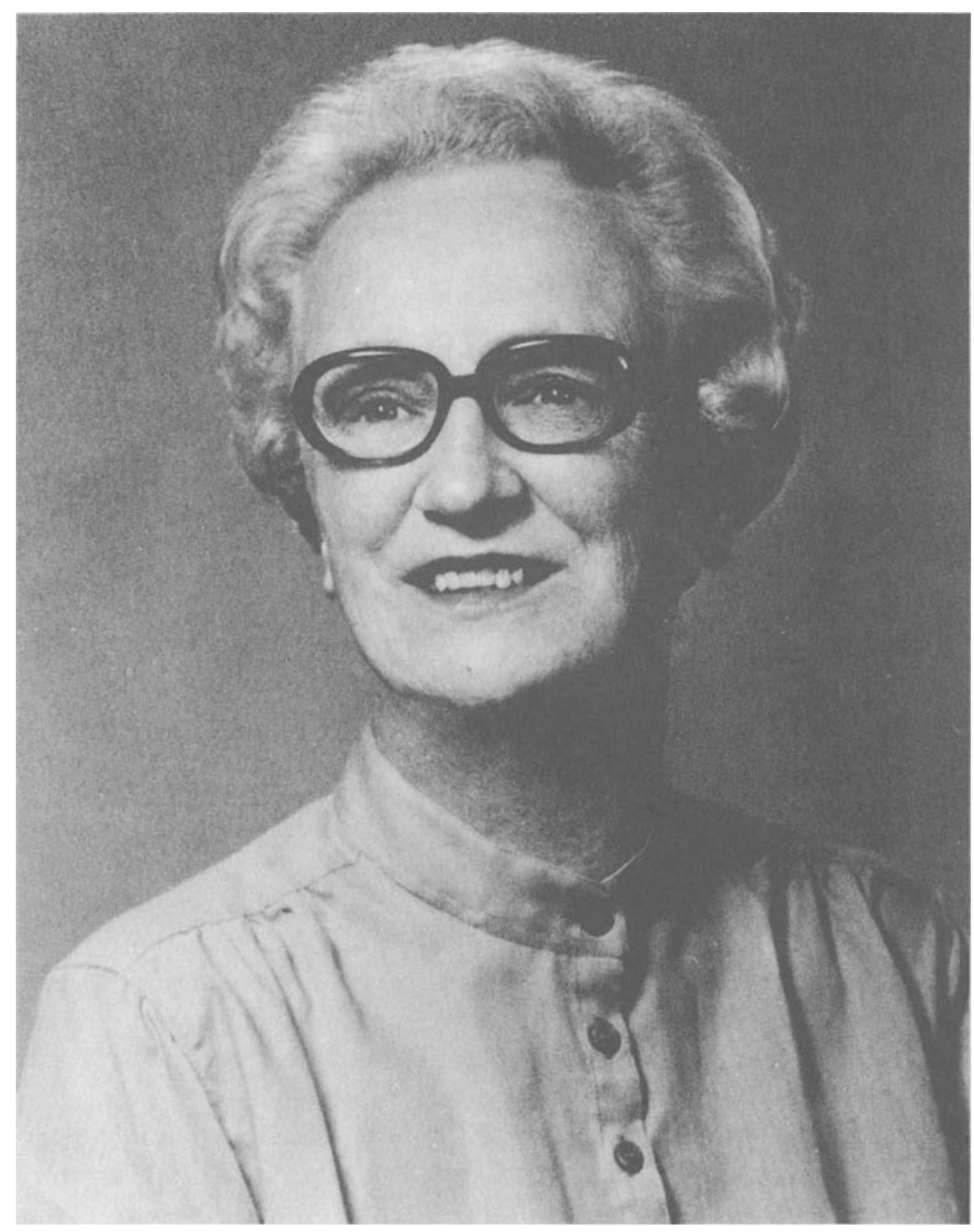

HILDEGARD E. PEPLAU 


\section{Foreword}

I have known Hilda Peplau for over forty years. I count myself as friend, colleague and student. Not a student of Peplau, but a student with Peplau. When one studies with Hilda the study is of the data. This wise, caring, and gentle person is one of the finest and best scholars the profession has known. Someone has said that scholarship requires the discipline of the examined life. Hilda is the epitome of scholarship. For over sixty years her scholarship has been evocative, informative, and provocative. The present work is no exception.

In the early 1950s Peplau introduced an interpersonal relations paradigm for the study and practice of nursing (Peplau, 1952). The paradigm held that nurse and patient participate in and contribute to the relationship and, further, that the relationship itself could be therapeutic. This relationship could be examined, and through that examination would come teaching and learning. Since 1952 Peplau has extended many of her ideas. She continues to work with the issues generated by the paradigm.

The collective thinking of nurses about the practice of nursing has only recently become readily accessible to the professional community. Until the last decade, scholarship in nursing was more often than not shared with audiences through the spoken word. Many of Peplau's formulations, therefore, have not been accessible to the nursing profession at large. Many of her early contributions were published in obscure places-difficult to find or impossible to retrieve in current computer-based literature searches. Thus, this volume affords access to select segments of Peplau's work. These 
papers, compiled and edited by $\mathrm{O}^{\prime}$ Toole and Welt, are a joy to behold as well as a delight to read. It is a boon to psychiatric nursing that these editors have diligently worked to make Peplau's ideas viable and available for use in practice, teaching, and research.

Pragmatism suggests that we are obliged to test knowledge by asking what we would be required to do if we believe the paradigm to be true (Kaplan, 1964). Responses to that question can be generated from this volume. If the Peplau paradigm is to be believed, then nursing will be practiced differently from practice based on earlier models; nursing will be taught and learned differently from the modes currently prevailing; and nursing will be researched differently.

But in what ways would nursing be different? To practice nursing using the paradigm of interpersonal relations requires the development of new norms: norms that govern the conduct of practice. The papers in the volume devoted to the characteristics of social versus professional relationships are classic. Herein, guidelines are provided for therapeutic relationships that honor the integrity and self-worth of both nurse and patient. Given the recent spate of reported abuses by therapists in the course of treatment, these thoughtfully reasoned papers on the normative structure of the professional practice of the nurse are needed additions to the field of psychiatric nursing. I expect that nurses will integrate these ideas into their practice, as well as recommend these chapters to colleagues in other mental health disciplines.

A second major difference to be evidenced if one accepts the Peplau paradigm concerns the teaching and learning of relationship skills and processes. In this area the editors have chosen some of the very best of Peplau's work. The experiential mode of teaching and learning has been central to Peplau's thinking. Her basic thrust is that people will grow and change when they can learn to sustain the discomfort connected with examination of the experience, while utilizing new ideas and new responses.

The third area that would be conducted differently from the perspective of the Peplau paradigm is the study of clinical phenomena of concern in nursing practice. This volume includes classic papers demonstrating both the development of theoretical constructs from clinical data and the testing of theoretical constructs using that data. 
No one does it better than Peplau! In these chapters one feels the excitement derived from operationalizing clinical phenomena, for instance, loneliness. Also evident is the thoughtful, systematic, and disciplined approach to the work of assisting patients to learn through the examination of their experiences.

Macmillan of London has reissued Peplau's 1952 book, Interpersonal Relations in Nursing. That seminal text and this volume together bring Peplau's ideas to nursing at a time when the field has the capacity to receive and use the work in substantive ways. In the 1990s there are the scholars, the well prepared researchers, and indeed the collective intellectual energy available to advance $\mathrm{Pe}-$ plau's ideas in the service of both the profession and society. As the reader embraces this volume, in the spirit of interpersonal relationships, and to paraphrase Kaplan (1964), I say: "May it do you much good and may you do it much good."

\author{
Grayce Sills, R.N., Ph.D., F.A.A.N. \\ Ohio State University \\ Columbus, Ohio
}

\title{
References
}

Kaplan, A. (1964). The conduct of inquiry. New York: Chandler.

Peplau, H. E. (1952). Interpersonal relations in nursing. New York: Putnam.

Reissued by Macmillan, London, 1988. 


\section{Acknowledgments}

This book has been germinating in our minds for much of our professional lives. Until we seriously considered the project, historical research was merely an impressive term. For two years, however, we have labored and learned a great deal about the historical research process and have admiration for those hearty souls who pursue it. We were helped immeasurably by Dr. Patricia King and her staff at the Arthur and Elizabeth Schlesinger Library on the History of Women in America at Radcliffe College, where the Hildegard E. Peplau Archives are housed. This research was supported in part by funds given by Radcliffe College for research at the Schlesinger Library. We are also grateful for financial support from Kent State University Research and Sponsored Programs, and Kent State University School of Nursing.

Without Hilda, of course, there would be no book. We can no longer complain to her that much of her work that we had wished were in print remains unpublished. Although there is much more where this came from, we have made a start. In a way, our considerable effort is a tribute to her as our mentor. As our teacher, our supervisor, our scholarly clinical role model, she taught us about logical thinking, the scientific method, and perseverance. As our mentor, her "tender (and sometime not so tender) cooperation" assured that our clinical and theoretical needs took precedence, that our learning was primary, that the development of our selves was paramount. We thank her for her unflagging concern, for her knowledge and desire to share it, and for her discipline that surely we have internalized. Her marvelous intellect and wonderful mind, always 
seeking knowledge and encouraging others in their quests, have inspired us to question - and certainly because we were free to do so, we have had some moments together far apart in our opinions. We have grown up with Hilda, personally and professionally. She is now our mentor, our colleague, and our friend and we cherish our relationship and her legacy. Our lives would not have been the same without her.

Without each other it is doubtful we could have produced this book. When one of us doubted, wavered, or faltered, the other held up. And without similar obsessional minds, complementary styles, and humor, cooperation and collaboration would have been impossible. Our relationship with Hilda and each other has deepened through the experience of so carefully studying our professional roots. The experience is indelibly with us.

To our husbands, Richard and Aaron, we give extended thanks and many rainchecks for time apart. Their support of our intellectual activity and appreciation of the need for and commitment to the project got us through the difficult times more easily than we would have otherwise. Their companionship, love, humor, and appreciation of Hilda was there more often than we knew we needed it.

To little William Philip Rouslin Welt - son of Sheila, and godson of Anita-who arrived near the end of the project, we give thanks for inspiring the much-needed creativity for the finish line. He surely has the longest record for a newborn of time spent in a bassinet in a study! Certainly this baby will go into the 21 st century having internalized Peplau by proxy.

We sincerely thank Monika Ineman, who prepared the manuscript, for her excellent work. She had to decipher Peplau, O'Toole, and Welt-and that was no mean feat. We also thank Wendy Lewandowski for her assistance in the initial library search of published papers. The publishers and editors were there when we needed them, and let us proceed on our own when we did not. We hope this is the beginning of a fruitful Springer, Peplau, O'Toole, and Welt interpersonal relationship. 


\section{Introduction}

In 1952 the nursing world was formally introduced to interpersonal theory by Hildegard E. Peplau. Nursing has never been the same since. Peplau's influence on nursing and particularly psychiatric nursing has been enormous. She is often referred to as the mother of psychiatric nursing, a designation that is well deserved, because she spawned a new generation of psychiatric nurses who learned to use theory, specifically interpersonal theory, in their therapeutic work with patients.

This book presents a selection of Peplau's best clinical and theoretical papers written between the years 1953 to 1988 . We decided to collect and edit her papers because most summaries of her theory encountered in nursing literature are based primarily, and often singularly, on her 1952 landmark book, Interpersonal Relations in Nursing. Although that work presented the most complete exposition of her theory of interpersonal relations, it was followed by decades of work to refine and elaborate upon that beginning. Unfortunately, many of the post-1952 papers were not published or are not readily available, having appeared in journals that are no longer available or in texts that are now out of print.

Fortunately, Peplau is a prodigious saver of her work. Her papers were solicited for an archival collection by the Arthur and Elizabeth Schlesinger Library on the History of Women in America at Radcliffe College, Harvard University. The Hildegard E. Peplau Archives consist of 46 cartons containing personal letters and documents; papers, notes, and records from her college years; professional correspondence, lectures, unpublished papers, and 
workshop materials; correspondence and papers related to her positions in professional organizations; and publications. All but the personal documents are open to researchers.

The method for selecting the papers to be published involved several steps. (1) We obtained a copy of all Peplau's published papers through interlibrary loan services and reviewed the published works. (2) Peplau contributed papers from her personal files that had not been published or contributed to her archives. (3) The archive collection at Schlesinger Library was reviewed during two periods: July 20 to 25, 1986 and October 5 to 10, 1986. (4) Papers were selected for copying from the collection if they met predetermined criteria: papers not previously published, papers that contributed to theory development in psychiatric nursing, and letters or notes that provided background information about the papers. That part of the collection open for researchers was reviewed, including: Series II: School, College, Career; Series III: Professional Activities; Series IV: Organizations; and Series V: Writings (Knowles, Dolan, King, \& Fraser, 1984). The contents of 32 cartons were surveyed and 138 documents were selected for copying and further review. (5) Papers were sorted by content category (clinical/theoretical, professional issues, and educational methods) and reviewed by both editors for clarity, value of contribution, and repetition. Papers selected for this publication were limited to those related to clinical and theoretical issues, and educational methods. Peplau was consulted to verify the professional and historical context of the papers noted in the introductions to each section.

The book is divided into five major sections: Part I includes papers related specifically to interpersonal relations theory. Part II addresses therapeutic milieu and includes concepts such as pattern interaction, pattern maintenance, and prevention of chronicity. Part III contains three papers on the teaching of psychiatric nursing: experiential teaching, techniques of interpretation, and clinical supervision. Part IV is about psychotherapy and addresses interviewing techniques and other aspects of the nurse-patient relationship including thematic abstraction. And Part V includes papers on the major concepts that form the backbone of Peplau's interpersonal theory: loneliness, anxiety, self, hallucinations, thought 
disorders, focal attention, and learning. The final chapter, Editors' Summary, is a synopsis of Peplau's major ideas.

In order to place Peplau's work in context it is important to review aspects of her personal and professional biography. Hildegard E. Peplau was born on September 1, 1909 in Reading, Pennsylvania, the second daughter of Gustav and Ottylie Peplau. Both of Hilda's parents were immigrants to the United States; they were of German origin, although born in Poland (H. E. Peplau, personal communication, August 5, 1988). Hilda was one of six children, three girls and three boys. As a child she witnessed the major flu epidemic of 1918 , an event that had a profound influence on her understanding of the impact of illness and death on families.

Peplau graduated from Pottstown, Pennsylvania Hospital School of Nursing in 1931. She received a B.A. in psychology from Bennington College, Vermont in 1943. She received her M.A. in psychiatric nursing in 1947 and Ed.D. in nursing education in 1953, both graduate degrees from Teachers' College, Columbia University. She was certified in Psychoanalysis for Teachers by the William Alanson White Institute of New York City in 1954 (Knowles et al., 1984).

After graduating from nursing school in 1931, Hilda worked as a private duty and general staff nurse in Pennsylvania. During summers she served as a camp nurse for the New York University summer camp. In an interview for Geriatric Nursing (1986) Hilda recounted the significance of the summer camp position to her subsequent education. She was recommended for the camp position by a female physician, for whom Hilda served as a tennis partner during her student years. The camp director recommended her for the position of College Health Service Nurse at Bennington College, where she came into contact with the president of the college who, recognizing her ability, offered her a full scholarship. She had her first exposure to interpersonal theory while a student at Bennington where she studied with Erich Fromm and later with Frieda FrommReichman in a field study experience at Chestnut Lodge, Rockville, Maryland (Knowles et al., 1984). There she attended lectures by Harry Stack Sullivan and began her lifelong endeavor to interpret and extend Sullivanian theory for use in nursing practice.

She served in the U.S. Army Nurse Corps from 1943 to 1945 and was assigned for most of that period to the School of Military 
Neuropsychiatry in England, where she came into contact with the top psychiatrists of the world (Peplau, 1981). After receiving her master's degree from Teachers' College, she taught there from 1948 to 1953 as an instructor and director of the Advanced Program in Psychiatric Nursing. It was during this period as a faculty member at Teachers' College that Peplau formulated many of her theories. The book Interpersonal Relations in Nursing was completed in 1948. It was not published until four years later because it was considered too revolutionary for a nurse to publish such a book without a physician as coauthor. Peplau developed the classes for graduate level psychiatric nursing students at Teachers' College, with a strong emphasis on direct clinical experience with psychiatric patients. She began as early as 1948 to require that students interview patients, record those interviews, and study them for recurring themes and patterns of interaction. From these notes and her own clinical experience she formulated operational definitions of concepts: for example, anxiety, learning, conflict, and frustration.

She was a private duty nurse in New York City from 1953 to 1955; from that experience came data for her work on loneliness (H. E. Peplau, personal communication, August 5, 1988.) In 1954 she was employed part time and then full time in 1955 by the College of Nursing, Rutgers University, where she became chairperson of the Department of Psychiatric Nursing and Director of the Graduate Program in Psychiatric Nursing. There she developed the first graduate program devoted exclusively to the preparation of clinical specialists in psychiatric nursing. She was promoted to professor in 1960 and retired as professor emerita in 1974. She maintained a part-time private psychotherapy practice from 1958 until her retirement.

During her tenure at Rutgers she became widely known for the summer clinical workshops she conducted for nurses (mostly in state psychiatric hospitals) throughout the country. She taught interviewing techniques, personality theory, family and group therapy, and advocated that nurses become educated so they could provide therapeutic care and reverse the trend toward chronicity characteristic of state mental institutions. Through these clinical workshops and her frequent presentations at professional meetings she became an ambassador for advanced education for nurses and 
an advocate for the plight of the mentally ill. Most nurses who experienced a Peplau workshop came away changed for life; many went on to further their education and make significant contributions to psychiatric nursing. As one nurse said, "Peplau has a way of stretching your intelligence."

Peplau's influence on students who studied with her at Teachers' College and Rutgers was profound. She is a mentor in the truest sense of the word, one who respects the autonomous development of a learner and provides a model of a disciplined scholar to emulate. She is one of the early nursing educators to recognize and develop teaching methods for intervening in the self-concept problems women experienced as learners in higher education in a time and culture that discouraged women and particularly nurses from pursuing careers as scholars. Many of the nurses who studied with her went on to become leaders in nursing.

Peplau was executive director of the American Nurses' Association from 1969 to 1970, president from 1970 to 1972, and second vice-president from 1972 to 1974 . She served as third vice-president and board member for the International Council of Nurses from 1973 to 1981 . After her retirement from Rutgers in 1974, she served as a World Health Organization consultant and visiting professor at the University of Leuven in Belgium for two periods, 1975 and 1976 to 1977 (Knowles et al., 1984). Hilda now resides in Sherman Oaks in Los Angeles and continues to lecture and write, heeding her own advice, "If you don't use it, you'll lose it."

\section{REFERENCES}

Geriatric Nursing (Interview). (1986, November/December). Hildegard E. Peplau: Grande dame of psychiatric nursing (pp. 328-330).

Knowles, J. S., Dolan, M., King, S., Fraser, C. L. (1984, October). Hildegard Elizabeth Peplau papers. Unpublished preliminary inventory, Schlesinger Library, Radcliffe College, Cambridge, MA.

Peplau, H. E. (1952). Interpersonal relations in nursing. New York: Putnam. (Reissued, 1988. London: Macmillan)

Peplau, H. E. (Speaker). (1981). Peplau on Peplau. Cassette Recording. Schlesinger Library, Radcliffe College, Cambridge, MA. No. 84-M107 Hildegard E. Peplau Archives, carton 31, volume 1151. 


\section{Introduction to this Edition}

It is a number of years since I undertook my mental health nurse training. When I see the changes that have taken place in that time: old mental hospitals closing; community care programmes developing; working with other professionals as an effective team on a more equal basis; development of nursing in its own right; I feel a book such as Peplau's selected works is both relevant and useful to today's practitioners.

Although the papers in this book stem from Peplau's experiences of mental nursing care in the United States, there is without doubt a positive benefit for reading this book and applying some of her ideas and theories to the United Kingdom mental health nursing scene.

Part I discusses the interpersonal relations theory. This section is certainly relevant to British nursing practitioners. The reference to role expectations in the nurse-patient relationship is of particular use, as nurses now rely heavily on their own professional resources as key workers, most obviously in community care settings. In chapter 3 Peplau looks at the purpose and characteristics of professional nursing and this seems timely, as much of the understanding of mental health nursing is connected to nurses in the United Kingdom seeing themselves as professionally different yet complementary to other health care groups.

Part II, on therapeutic milieu, brings together very helpful ideas about caring for patients/clients in Great Britain. It touches on a number of important professional issues: responsibility, competency, roles of nurses and changing perceptions of care. Even 
though this work was written some time ago, the forward thinking of Peplau has enabled the concepts of the therapeutic alliance to span time very effectively.

Part III, on the teaching of psychiatric nursing, has a lot to offer the nurse studying at pre- and post-registration levels. The short chapter on clinical supervision of staff nurses reminds us of the important issues currently being developed in the British nursing system, that of preceptorship and mentorship of newly qualified nurses.

Part IV, on psychotherapy, gives us an opportunity to review our insight and experience in mental health nursing. The use of some terms may feel slightly strange in this part, but it will equip a nurse with ideas on developing skills in mental health care. The chapters on investigative counselling and professional closeness are particularly helpful.

Part V, on concepts, draws together the underlying principles of Peplau's thinking. This is projected through the chapters on loneliness, concepts of anxiety, self and hallucinations, and nursing behaviour and language of patients.

The overall value of this book is the bringing together of three important professional needs and expectations of a mental health nurse: firstly, the study of theoretical concepts so providing a firm foundation on which to practise nursing; secondly, the development of nursing skills to a very effective level; and thirdly the development of self as a professional in a multicultural health setting. 
Through ambition alone you cannot reach your goal. You must have assistance from trained minds. Minds who like yours craved knowledge and found it.

Hildegard E. Peplau

Circa 1927

From "The Goals of Our Lives and the Paths That Lead to It." Writings of E. H. Peplau and Selected Articles. Schlesinger Library, Radcliffe College, Cambridge, MA. No. 84-M107, Hildegard E. Peplau Archives, carton 8, volume 264. Copyright 1986 by Schlesinger Library. Reprinted by permission. 